\title{
Nutrient Digestibility of Forage and Nonforage Rations in the Ruminant ${ }^{1,2}$
}

\author{
José A. Arroyo-Aguilú and Joe L. Evans
}

\begin{abstract}
Pooled data from forage and nonforage digestibility trials with steers were analyzed. Forages were higher in total fiber content, principally cellulose; nonforages were lower in total fiber content, principally hemicellulose. The fiber fractions of forages and non-forages both together and separately were regressed upon their respective digestible fractions $(P<.01)$. The results indicated significant linear relationships and coefficients of variation for the digestible fraction estimated from the total ranged from 4 to 20 percent. Regression of digestible upon total holocellulose $(\mathrm{P}<.01)$ indicated a greater association than either of the regressions of cellulose or hemicellulose. Cellulose content and lignification contributed 85 percent $(P<.01)$ and 12 percent $(P<.01)$ to digestible cellulose, respectively. Hemicellulose content and lignification explained 74 percent $(P<.01)$ and 0.6 percent, respectively, of the variation in digestible hemicellulose. Neutral detergent soluble digestibility is highly dependent on ration cellulose and hemicellulose content, due possibly to rates of passage and digestion of the fibrous fractions. Differences in digestibility between forages and nonforages were attributed to differences in the total fiber fractions, indicating there was a continuum between concentrates and forage, when all rations were considered.
\end{abstract}

\section{INTRODUCTION}

The nutritive evaluation of feedstuffs is a very important part in the production, improvement and utilization of feeds (roughages, concentrates or a mixture of both) for animals, especially for ruminants. Nutritive value is a function of chemical composition and digestibility which, in turn, may be influenced by plant species, date of harvest, latitude and fertilization rates. The amount of carbohydrate may vary widely depending upon the source of roughages, concentrates, or a combination of both which constitute a complete feed. For ruminant animals, the amount and nutritional quality of the carbohydrate fractions are of particular importance due to

1 Manuscript submitted to Editorial Board December 27, 1973.

2 Paper of the Journal Series, New Jersey Agricultural Experiment Station, Cook College, Rutgers University, New Brunswick, N. J. This study was supported in part by Hatch funds. Data taken in part from a thesis submitted by the senior author to the Graduate Faculty in partial fulfillment of the requirements for the degree of Doctor of Philosophy.

Associate Nutritionist, Animal Husbandry Department, Agricul tural Experiment Station, Mayagüez Campus, University of Puerto Rico, Río Piedras, P.R., and Professor of Nutrition, Animal Science Department, Cook College, Rutgers University, New Brunswick, N. J., respectively. 
the physiology of the digestive tract which includes a rumen or fermentation vat.

A new scheme for the fractionation of feed dry matter was introduced by Van Soest $(14,15,17)$, based on the nutritional availability of the chemical fractions: cellular contents or neutral-detergent solubles (NDS) and cellwall constituents or neutral-detergent fiber (NDF). The completely available NDS fraction is composed of soluble carbohydrates, most proteins and other water-soluble matter. The total fiber fraction (18) is the partially and nonuniformly available NDF fraction, consisting of hemicellulose $(\mathrm{H})$, cellulose (C) and acid-detergent lignin (L) (15). Total digestibility is the overall digestibility of NDF and NDS.

This study reports the combined effects of forage (3) and nonforage (1) rations on digestibility of ration components in ruminant animals.

\section{PROCEDURE}

Chemical composition and digestibility data were obtained from a forage study by Colburn et al. (3), and from a complete feed study by ArroyoAguilú and Evans (1). Complete feeds will be referred to in this study as nonforages.

The forage data included 17 forages: 16 orchardgrass hays (eight first harvests and eight aftermaths) harvested in Northern New Jersey, and alfalfa hay harvested in Central New Jersey (3). A total of four individual digestion observations using steers were made on each of the 16 orchardgrass hays and three on the alfalfa hay, for a total of 67 collection trials. The orchardgrass plots were fertilized at the rate of $90 \mathrm{~kg}$ of nitrogen (N) per ha for each of three applications per year. All hays were dried in a forced-air dryer at $65^{\circ} \mathrm{C}$, then chopped through a Wetmore hammer mill to a length ranging from one to eight $\mathrm{cm}$.

The nonforage data included 14 complete rations, $N$ sources being corn gluten for six rations; toasted soybean for two rations; raw soybean for two rations; urea for two rations; wheat gluten for one ration; and a mixture of toasted soybean and urea for one ration (1). Other ingredients, common to all rations, were corn starch, corn cobs, soybean oil, molasses, minerals, vitamins and choline chloride (1). A total of 140 collection trials using steers were conducted (1).

Feed, ort and fecal samples were collected daily and composited for each 6-day and each 3-day (nonforage data) collection. Samples were dried to a constant weight in a forced-air oven at $45^{\circ} \mathrm{C}$, ground in a Wiley mill to pass a 1-mm screen, and allowed to air equilibrate before storage for chemical analyses.

Analyses for dry matter and Kjeldahl $\mathrm{N}$ were determined by A.O.A.C. methods (2). Analysis for NDF was determined as described by Goering 
and Van Soest (S). Acid-detergent fiber (ADF) and L (sulfuric acid method) were determined essentially as outlined by Goering and Van Soest (8), except that $75 \mathrm{ml}$ of the detergent solution were added to a $0.5-\mathrm{g}$ sample. For the determination of $\mathrm{C}$, a slight modification of the Crampton and Maynard method (4) was used. Regression equations to predict C (1) werè employed, and $\mathrm{H}$ was represented by $\mathrm{NDF}$ minus $\mathrm{ADF}$.

Statistical analyses were performed according to Snedecor and Cochran (12).

TABLE 1.-Mean chemical composition of feeds and some simple correlation coefficients of these components to percent digestible dry matter

\begin{tabular}{|c|c|c|c|c|c|c|c|c|}
\hline & \multicolumn{8}{|c|}{ Chemical composition of feed² } \\
\hline & $N \times 6.252$ & $\begin{array}{c}\text { NDS } \\
\mathrm{N} \times 6.25\end{array}$ & $\mathrm{~N}^{\mathrm{NDF}} \times 6.25$ & H & C & L & ADF & NDF \\
\hline \multirow[t]{2}{*}{ Range } & $\begin{array}{l}\text { Percent } \\
16.7 \\
11.5 \\
-25.8\end{array}$ & \begin{tabular}{|c} 
Percent \\
11.6 \\
5.8 \\
-22.5
\end{tabular} & $\begin{array}{l}\text { Percent } \\
5.1 \\
2.5 \\
-10.6\end{array}$ & $\begin{array}{l}\text { Percent } \\
23.1 \\
11.4 \\
-38.7\end{array}$ & $\begin{array}{l}\text { Percent } \\
17.7 \\
5.7 \\
-33.5\end{array}$ & $\begin{array}{l}\text { Percent } \\
3.2 \\
1.3 \\
-5.2\end{array}$ & $\begin{array}{l}\text { Percent } \\
21.1 \\
8.2 \\
-39.2\end{array}$ & $\begin{array}{l}\text { Percent } \\
44.2 \\
27.5 \\
-70.5\end{array}$ \\
\hline & \multicolumn{8}{|c|}{ (Simple correlation coefficients) } \\
\hline $\begin{array}{l}\text { DDM (per- } \\
\text { cent) }\end{array}$ & $-0.15^{* 3}$ & 0.04 & $-0.27^{* * 4} \mid$ & $-0.41^{* *}$ & $-0.81 * *$ & $-0.74^{* *}$ & $-0.82^{* *}$ & $-0.80^{* *}$ \\
\hline
\end{tabular}

${ }^{1}$ Data included 207 collection trials from Jersey steers; 67 were consuming forage rations (3) and 140 complete rations (1).

$2 \mathrm{~N} \times 6.25$, crude protein; NDS, neutral-detergent solubles; NDF, neutral-detergent fiber; $H$, hemicellulose; $C$, cellulose; L, lignin; ADF, acid-detergent fiber; DDM, digestible dry matter.

3 * Significant at the 5-percent level.

4** Significant at the 1-percent level.

\section{RESULTS AND DISCUSSION}

The composition of the feeds pooled in this study were different, the forage being higher than the nonforage rations in NDF content. Orchardgrass and alfalfa forages used in the all-forage study were higher in total fiber content, principally C. Complete feeds used in the nonforage study, consisting mainly of corn cobs, cornstarch, beet pulp and molasses, were lower in total fiber content, principally $\mathrm{H}$. However, both ration groups contained similar amounts of $\mathrm{L}$.

\section{APPARENT DRY MATTER DIGESTIBILITY}

Mean chemical composition data and coefficients of correlation for digestible dry matter (DDM) and constituents are presented in table 1. As NDF content increased, DDM $(P<.01)$ decreased, thus showing the 
influence of the fiber fraction upon DDM. Sullivan (13) demonstrated that higher fiber contents are associated with lower digestibility in both grasses and alfalfa. As a result, the total fiber content, whether constituted mostly by $\mathrm{C}, \mathrm{H}$ or both, may be a good predictor of the DDM.

The $C$ content of nonforages (1) and the $H$ content of forages (3) were probably responsible for the increased significant correlation $(\mathrm{P}<.01)$ between DDM with $\mathrm{C}$ and with $\mathrm{H}$ in all feeds, respectively. As a result, a positive significant correlation of $0.43(\mathrm{P}<.01)$ in all feeds between $\mathrm{C}$ and $\mathrm{H}$ content best explained their association to DDM. Between $\mathrm{C}$ and $\mathrm{H}$, nonforages (1) exhibited a negative relationship $(r=-.17)$ while forages (3) exhibited none $(r=.00)$.

The $\mathrm{L}$ fraction was also negatively associated $(\mathrm{P}<.01)$ to $\mathrm{DDM}$, being influenced by the negative effect $(P<.01)$ from both forages and nonforages. Sullivan (13) and Van Soest (16) have obtained similar correlations $(P<.01)$ between DDM with $L$ and with other forms of $L$, respectively. Lignin (1) alone accounted for 55 percent $(P<.01)$ of the difference in DDM for the pooled data, while $\mathrm{C}$ and $\mathrm{H}$ contributed 9 percent and 3 percent $(P<.01)$, respectively. For nonforage data (1) alone, $L$ explained 52 percent $(\mathrm{P}<.01)$ of the difference in DDM. For the forage data (3), $\mathrm{L}$ accounted for 40 percent $(P<.01)$ of the difference in DDM, while $H$, $\mathrm{N}$ and $\mathrm{C}$ each contributed 16, 4 and 4 percent, respectively. Thus, $\mathrm{L}$ explained over 40 percent of the variation in DDM, both in forages and in nonforages.

In the forage data (3), DDM tended to increase $(\mathrm{P}<.01)$ as total $\mathrm{N}$ and NDS $N$ content increased, but to decrease as NDF $N$ increased. All nonforage data (1) followed the same trend; however, when the data were pooled, DDM tended to decrease with an increase in $\mathrm{N}(\mathrm{P}<.01)$ but to increase with an increase in NDS N.

It may be indicated that the greatest contribution to DDM in the pooled, as well as in the nonforage (1) and forage (3), data was accounted for by the total fiber fraction, mainly the $\mathrm{L}$ content. However, $\mathrm{C}$ showed a marked influence $(\mathrm{r}=-.81)$ upon DDM in the pooled data.

\section{FIBROUS FRACTIONS}

The $\mathrm{C}$ and $\mathrm{L}$ fractions together make up the $\mathrm{ADF}$ fraction. This, in turn, together with $\mathrm{H}$ and some $\mathrm{N}$, form the NDF fraction.

A positive relationship $(P<.01)$ between digestible and total NDF (table 2) exists, when employing regression analysis (10). This association appears to be less constant ( 19 percent CV) than those obtained in nonforage (1) and forage (3) data. Similar correlations were obtained in forages $(6,17)$.

Digestible $\mathrm{C}$ and $\mathrm{H}$ of pooled data, as indicated by coefficients of cor- 
TABLE 2.-Regression equations of form $\mathrm{Y}=\mathrm{k}+\mathrm{bX}^{1}$ showing relationships between digestible and total chemical components in the feed dry matter ${ }^{1}$

\begin{tabular}{|c|c|c|c|c|c|}
\hline \multirow{2}{*}{$\begin{array}{c}\text { Chemical } \\
\text { component }\end{array}$} & \multicolumn{2}{|c|}{ Equation } & \multicolumn{2}{|c|}{ Coefficient } & \multirow{2}{*}{$\begin{array}{c}\mathrm{SE} \text { of regression } \\
\text { coefficient }\end{array}$} \\
\hline & Constant & $\begin{array}{l}\text { Regression } \\
\text { coefficient }\end{array}$ & $\begin{array}{c}\text { of } \\
\text { variation }\end{array}$ & $\begin{array}{c}\text { of } \\
\text { correlation }\end{array}$ & \\
\hline & $k$ & $b$ & Percent & $r$ & \\
\hline $\mathrm{N} \times 6.25^{3}$ & -1.9 & 0.86 & 6 & $0.96^{* * 4}$ & 0.02 \\
\hline NDS & -19.7 & 1.16 & 5 & $.99 * *$ & .02 \\
\hline NDF & -8.3 & .80 & 19 & $.89^{* *}$ & .03 \\
\hline $\mathbf{H}+\mathbf{C}$ & -4.3 & .77 & 9 & $.96^{* *}$ & .08 \\
\hline $\mathbf{H}$ & -4.1 & .83 & 15 & $.89 * *$ & .03 \\
\hline C & -4.0 & .89 & 13 & $.98 * *$ & .02 \\
\hline
\end{tabular}

$Y, k, b$ and $X$ equal percent digestible nutrient, endogenous fraction, true coefficient of digestibility and total nutrient, respectively.

$2 \mathrm{SE}$, standard error.

8 $\times$ 6.25, crude protein; NDS, neutral-detergent solubles; NDF, neutral-detergent fiber; $\mathrm{H}+\mathrm{C}$, holocellulose; $\mathrm{H}$, hemicellulose; $\mathrm{C}$, cellulose.

1** Significant at the 1-percent level.

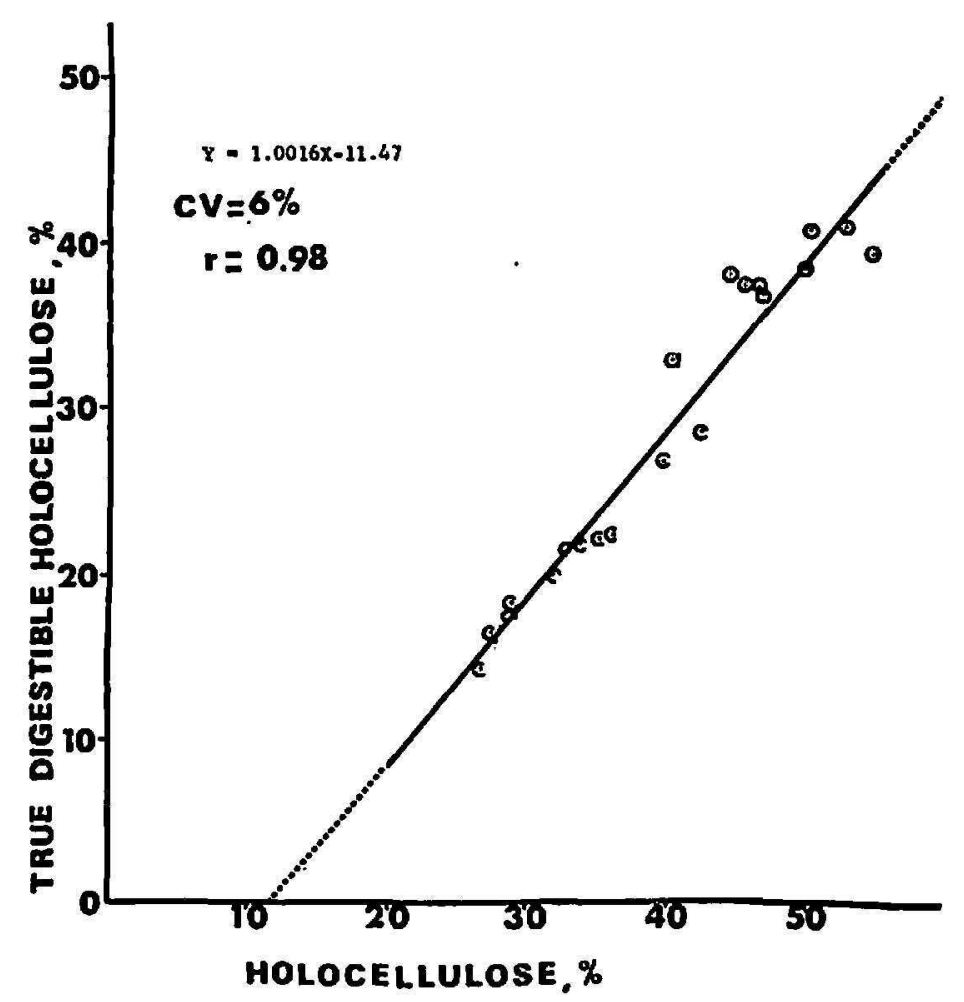

Fig. 1.-Regression of the digestible on the total holocellulose content in orchardgrass $(0)$, alfalfa (a), and low-fiber non-forage (c) rations.

relation and variation, tended to be more related $(\mathrm{P}<.01)$ to their total ration contents than the same fractions in nonforage (1) or forage (3) samples. Cellulose and $H$ together make up the holocellulose fraction which, upon regression with its digestible amount (fig. 1), provided a greater 
correlation coefficient $(\mathrm{r}=.96)$ than either $\mathrm{C}$ or $\mathrm{H}$ separately, suggesting a degree of uniformity for the total fiber fraction, holocellulose, which is partly but not necessarily completely digestible in the absence of $\mathrm{L}$.

Prediction of percent digestible $\mathrm{C}(Y)$ was expressed by the equation $Y=-5.16+0.76 X_{1}+0.66 X_{2}$, where $X_{1}$ and $X_{2}$ represented percent $\mathrm{C}$ content and the ratio of percent $C$ to percent $L$ (lignification), respectively. Cellulose content and lignification accounted for 97 percent of the difference in digestible $\mathbf{C}$ (table 3 ). In contrast to these results, nonforage data (1) and forage data (3) contributed 98 and 91 percent, respectively, to the difference in $\mathrm{C}$ digestibility (table 3 ). The data suggested that lignification

TABLE 3.-Partial regression and correlation coefficients showing relationships between digestible cellulose or hemicellulose with total cellulose or hemicellulose and lignification in the feed dry matter

\begin{tabular}{|c|c|c|c|c|c|c|c|c|}
\hline & \multirow{3}{*}{$\frac{\text { Content }}{k}$} & \multicolumn{7}{|c|}{ Coefficient of } \\
\hline & & \multicolumn{2}{|c|}{$\underset{\text { regression! }}{\text { Partinl }}$} & \multicolumn{2}{|c|}{$\begin{array}{l}\text { Standard partial } \\
\text { regression }\end{array}$} & \multicolumn{2}{|c|}{ Partial correlation } & \multirow{2}{*}{$\begin{array}{c}\begin{array}{c}\text { Varia- } \\
\text { tion }\end{array} \\
C V\end{array}$} \\
\hline & & $x_{1}$ & $x_{1}$ & $X_{z}$ & $x_{2}$ & $x_{1}$ & $x_{2}$ & \\
\hline \multicolumn{9}{|c|}{ Cellulose } \\
\hline Forages & -5.65 & 0.46 & 0.38 & 0.74 & 0.34 & $0.79^{* * 2}$ & $0.54^{* *}$ & 11 \\
\hline Nonforages & -5.18 & .69 & .83 & .88 & .20 & $.88^{* *}$ & $.45^{* *}$ & 18 \\
\hline Pooled & -5.16 & .76 & .66 & .83 & .18 & $.92^{* *}$ & $.35^{* *}$ & 11 \\
\hline \multicolumn{9}{|c|}{ Hemicellulose } \\
\hline Forages & 2.89 & 0.47 & 0.15 & 0.82 & 0.13 & $0.84^{* *}$ & $0.26^{* *}$ & 6 \\
\hline Nonforages & -2.41 & .76 & .13 & .78 & .08 & $.77^{* *}$ & $.24^{* *}$ & 18 \\
\hline Pooled & 0.21 & .57 & .25 & .74 & .16 & $.86^{* *}$ & .08 & 9 \\
\hline
\end{tabular}

${ }^{1} X_{1}$ is level of nutrient; $X_{2}$ is ratio of nutrient to lignin.

$2 * *$ Significant at the 1-percent level.

is more important in forage rations (3), but that $\mathrm{C}$ content in both forage (3) and nonforage (1) rations provided a better index of potential DDM.

Digestible $H(Y)$ was regressed upon $H$ content $\left(X_{1}\right)$ and ratio of percent $\mathrm{H}$ to percent $\mathrm{L}\left(X_{2}\right)$ for the pooled data, resulting in an equation: $Y=$ $0.21+0.57 X_{1}+0.25 X_{2}$. Hemicellulose content explained 75 percent of the variation in digestible $\mathrm{H}$ with no contribution from lignification $(0.6$ percent) (table 3). As a result, $\mathrm{H}$ content provided a significant contribution to digestible $\mathrm{H}$ in the pooled data; however, lignification exerted an influence on nonforage (1) and forage (3) data when considered separately.

\section{NONFIBROUS FRACTIONS}

The average true digestion coefficients and the endogenous fractions for NDS and N were estimated from regression analysis (10). Digestible NDS was regressed upon total NDS and a correlation coefficient of .99 $(\mathrm{P}<.01)$, 
higher than that for all-nonforage (1) and all-forage (3) data, was obtained (table 2). Similar correlations have been obtained (5,6,17). Apparent digestible NDS was regressed on $\mathrm{C}, \mathrm{H}, \mathrm{L}$, and $\mathrm{N}$. Cellulose provided 84 percent of the difference in digestible NDS while $\mathrm{H}$ contributed 13 percent. These data suggested that NDS digestibility was highly dependent on $\mathbf{C}$ and $\mathrm{H}$ content of the diet, due possibly to rates of passage and digestion of the fibrous fractions.

Digestible $\mathrm{N}$ was regressed upon total $\mathrm{N}(\mathrm{P}<.01$ ) (table 2), and the results essentially agreed with the nonforage (1) and forage (3) data. Similar correlations $(P<.01)$ have been obtained for forages $(6,7,9,17)$ and for lower fiber feeds by Preston (11). True $\mathrm{N}$ digestibility and metabolic fecal $\mathrm{N}$ fractions were 86 and 1.9 percent (table 2), respectively, in contrast to those obtained from forage (87 and 2.8 percent) and nonforage (100 and 3.9 percent) (1) data. True $N$ digestibility and metabolic fecal $N$ fractions determined by Van Soest (17) for forages, and by Preston (11) for corn gluten meal were 93 and 3.1 percent, and 102 and 4.0 percent, respectively.

The negative influence of fiber-bound-N (NDF-N) on DDM $(\mathrm{r}=-.27)$ was related in part to the greater metabolic fecal protein loss with NDF-N versus NDS-N. However, to a certain degree an increase in fiberbound-N (less soluble) has resulted in an increase in retained $\mathrm{N}$ in ruminants.

\section{ESTIMATION OF APPARENT DRY MATTER DIGESTIBILITY}

Digestible NDF was higher in forages (42 percent) than in nonforages (20 percent). The inverse effect occurred for digestible NDS, showing the influence of NDF intake upon total DDM. Differences between nonforages and forages may be attributed to differences in the total fiber fractions. It can be concluded that feeds and forages have some qualities of concentrates as well as of roughages, and taking all feeds into consideration, there is a continuum between concentrates and forages.

\section{RESUMEN}

Los datos obtenidos en pruebas de digestibilidad con forrajeras y con concentrados (raciones completas) en novillos castrados fueron analizados conjuntamente. Los forrajes demostraron ser elevados en contenido de fibra total, principalmente celulosa. Los concentrados fueron bajos en fibra total, principalmente hemicelulosa. Las fracciones fibrosas de los forrajes y los concentrados se compararon con sus respectivas fracciones digestibles $(P<.01)$, juntas y por separado. Los resultados presentaron relaciones lineales significativas. Los coeficientes de variación para la fracción digestible estimada del total varió de 4 a 20 por ciento.

La regresión de la holocelulosa digestible en fracción de la holocelulosa total $(P<$ .01) proveyó una mayor asociación que cualquiera de las regresiones de celulosa o hemicelulosa. El contenido de celulosa y la lignificación contribuyeron $85(P<.01)$ y 12 por ciento $(P<.01)$ a la celulosa digestible, respectivamente. El contenido de hemicelulosa y la lignificación explicaron el $74(P<.01)$ y el 0.6 por ciento, respectivamente, de la variación en hemicelulosa digestible. Estos datos sugirieron que la 
digestibilidad del contenido celular depende en gran medida de la celulosa y hemicelulosa de la ración, debido posiblemente a la rapidez de pasaje y de digestión de las fracciones fibrosas.

Las diferencias en digestibilidad entre forrajes y concentrados se atribuyeron a las diferencias en las fracciones fibrosas totales, indicando que existe una continuidad entre forrajes y concentrados cuando se evaluan todas las raciones.

\section{LITERATURE CITED}

1. Arroyo-Aguilú, J. A., and Evans, J. L., Nutrient digestibility of lower-fiber rations in the ruminant animal, J. Dairy Sci. 55: 1266-74, 1972.

2. Association of Official Analytical Chemists, Official Methods of Analysis, 11th ed., Washington, D. C., 1970.

3. Colburn, M. W., Evans, J. L., and Ramage, C. H., Apparent and true digestibility of forage nutrients by ruminant animals, J. Dairy Sci. 51:1450-7, 1968.

4. Crampton, E. W., and Maynard, L. A., The relation of cellulose and lignin content to the nutritive value of animal feeds, J. Nutr. 15: 383-95, 1938.

5. Deinum, B., and Van Soest, P. J., Prediction of forage digestibility from some laboratory procedures, Neth. J. Agr. Sci. 17: 119-27, 1969.

6. Fonnesbeck, P. V., Partitioning the nutrients of forages for horses, J. Anim. Sci. 28: 624-33, 1969.

7. Glover, J., Duthie, D. W., and French, M. H., The apparent digestibility of crude protein by the ruminant, I. A synthesis of the results of digestibility trials with herbage and mixed feeds, J. Agr. Sci. 48: 373-8, 1957.

8. Goering, H. K., and Van Soest, P. J., Forage fiber analysis (apparatus, reagents, procedures, and some applications), AH 379, USDA, 1970.

9. Holter, J. A., and Reid, J. T., Relationship between the concentrations of crude protein and apparently digestible protein in forages. J. Anim. Sci. 18: 1339-49, 1959.

10. Lucas, Jr., H. L., Smart, Jr., W. M. G., Cipolloni, M. A., and Gross, H. D., Relations between digestibility and composition of feeds and foods, S-45 Report, N. C. State Coll., Raleigh, N. C., 1961.

11. Preston, R. L., Dynamics of protein utilization in ruminants, Proc. Nat. Feed Ing. Assoc., 1968.

12. Snedecor, G. W., and Cochran, W. G., Statistical Methods, 6th ed., The Iowa State University Press, Ames, Iowa, 1969.

13. Sullivan, J. T., The chemical composition of forages in relation to digestibility by ruminants, ARS, USDA, 34-62, 1964.

14. Van Soest, P. J., Use of detergents in the analysis of fibrous feeds, I, Preparation of fiber residues of low nitrogen content, J. Assoc. Off. Agr. Chem. 46: 825-9, 1963.

15. - Use of detergents in the analysis of fibrous feeds, II, A rapid method for determination of fiber and lignin, J. Assoc. Off. Agr. Chem. 46: 829-35, 1963.

16. - - Symposium on factors influencing the voluntary intake of herbage by ruminants: Voluntary intake in relation to chemical composition and digestibility, J. Anim. Sci. 24: 834-43, 1965.

17. - Development of a comprehensive system of feed-analysis and its application to forages, J. Anim. Sci. 26: 119-28, 1967.

18. - , and Wine, R. H., Use of detergents in the analysis of fibrous feeds, IV, The determination of plant cell-wall constituents. J. Assoc. Off. Anal. Chem. 50: 50-5, 1967. 